INDEPENDENT JOURNAL OF MANAGEMENT \& PRODUCTION (IJM\&P)

http://www.ijmp.jor.br

v. 11, n. 8, Special Edition ISE, S\&P - May 2020

ISSN: 2236-269X

DOI: 10.14807/ijmp.v11i8.1221

\title{
FINANCIAL RESOURCE BALANCE OF THE AGRICULTURAL SECTOR: CASE OF UKRAINE
}

\author{
Oksana Radchenko \\ National Scientific Center "Institute of Agrarian Economics", Ukraine \\ E-mail: nikolas68.72@mail.ru
}

Inna Tsvihun State Agrarian and Engineering University in Podilya, Ukraine

E-mail:innatsv@ukr.net

Iryna Yasinetska

State Agrarian and Engineering University in Podilya, Ukraine

E-mail:pro-navch@pdatu.edu.ia

Liubov Budniak

State Agrarian and Engineering University in Podilya, Ukraine

E-mail: budnyak.luba@gmail.com

Submission: $12 / 24 / 2019$

Accept: 1/7/2020

IJIM\&P

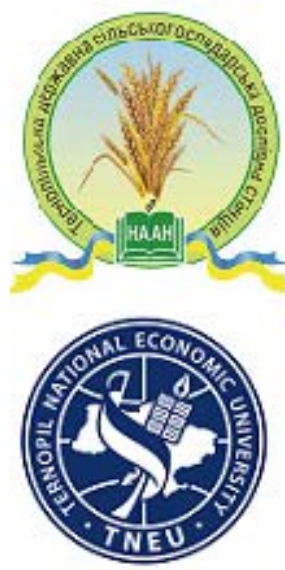

\section{ABSTRACT}

The study of financial balance is carried out in order to determine the supply and demand of financial resources for the agricultural sector and is to take into account the factors shaping the economic relations of the personified forms of capital movement. The balance of demand and supply of financial resources institutionally combines the resources of agricultural producers, credit institutions, financial institutions and the state and functionally it involves a set of the functions performed by financial regulation to achieve the goals of agricultural production. Since the concept of balance lies in the plane of financial and credit infrastructure, it is a system of normatively defined institutional and functional elements that form, regulate, mediate and develop financial relations and ensure the functioning of the agricultural sector by creating the resource potential of economic entities to carry out production on a permanent or extended basis. The methodological basis for the formation of the financial balance of the agricultural sector is enriched by new phenomena of domestic and foreign practice. Improving the methods of its formation and functioning is the basis for achieving sustainable long-term development of the agricultural sector and providing it with sufficient financial resources.

[https://creativecommons.org/licenses/by-nc-sa/4.0/legalcode]

Licensed under a Creative Commons Attribution 4.0 United States License 
DOI: 10.14807/ijmp.v11i8.1221

On this way, it is necessary to take into account both domestic and international experience. If the volume of potential financial resources of the agricultural sector in 2017 amounted to about 1024 billion UAH (37 billion US dollars), then for the period up to 2020 it is predicted that it can grow annually by no less than 215 billion UAH (15-20\%) in the next 3-5 years and by the end of 2020 against the level of 2015 will increase by 2.5 times. Sustainable agrarian development requires strategic planning of financial resources for a variety of their sources and state regulation of this process.

Keywords: Methodology; Balance; Financial Resources; Agricultural Production; Information Support

\section{INTRODUCTION}

Ukrainian legislation establishes the category "balance of financial resources" as a comprehensive forecast calculation, which displays the amount of generated financial resources and their use in all sectors of the state's economy. The method of its calculation was approved by the order of the Ministry of Economy No. 49/76/117 of April 18, 1996 (LUPENKO; MESEL-VESELIAK, 2012).

It is the basis for making management decisions on the effectiveness of the use of all types of financial resources, attracting additional investment sources, serves as an informational and analytical basis for the development and substantiation of the financial policy of the state. Balance indicators are calculated in close relationship with macroeconomic and social indicators. The forecast balance of financial resources is an integral part of the State Program of economic and social development of the country.

The forecast balance of financial resources is compiled by the relevant Ministry of Finance on the basis of data from sectoral ministries and state executive bodies. That aspect of the industry is the aim of our study. The resources of enterprises and organizations belong to the income of the Balance according to p. 2.4 in the mentioned Method (LUPENKO; MESEL-VESELIAK, 2012), which "consist of the profit remaining at their disposal, depreciation deductions, contributions of enterprises and organizations for road works and second incomes; to expenses", according to p. 3.3. "Expenses of enterprises and organizations at the expense of own resources" - "expenses of enterprises and organizations in the balance of financial resources within the limits of profit remaining at their disposal". Since the Methodology was developed in 1996, some of its aspects require revision and refinement, it can be implemented within the framework of expanding the informational role of data 
DOI: 10.14807/ijmp.v11i8.1221

analysis and clarifying the method of balancing financial resources on the example of the agricultural industry.

In addition, the balance of financial resources is a category of financial statements of enterprises, since it includes the Balance form, in which all resources are represented in the cash gauge. The purpose of the form is an assessment of the structure of the enterprise's resources, their liquidity and solvency, forecasting future borrowing needs, assessment and forecasting changes in economic resources, which the enterprise is likely to monitor in the future.

Information support and analysis of the formation of the financial balance of the agricultural sector is carried out in the plane of application of the established methodology of standard procedures for determining the amount of resources involved in servicing the financial support of strategies and concepts for the development of the agricultural sector, at least for the period of their operation. It is used to make informed management decisions related to the allocation of financial resources through: budget support; taxation system; investments; financial performance of agricultural enterprises; savings of the rural population; international financial assistance and so on.

Since the notion of balance is connected with financial policy and infrastructure, it enters the system of regulatory and institutional elements that form, regulate, mediate and develop financial relations and ensure the functioning of the economy, research and analysis of its methodology on the example of the economic sectors, in particular the agricultural sector and relevant scientific task.

\section{RESEARCH RESULTS AND DISCUSSION}

Famous Ukrainian scientists, such as: Demianenko and Lupenko (2012), Hudz (2015), Malik and Sabluk (14), Trusova (2017), Portna (2017), Korniychuk (2015), Shabatura (2015) and others have made a significant contribution to solving the problems of agrarian finance, their structure, sources and valuation methods.

The scientists' studies allowed forming a stable categorical apparatus for agrarian finance, which basically their determination on the aggregate of financial resources and incomes of economic entities (state, industry, enterprises) reflecting the availability and allocation of funds.

Foreign researchers of this subject are such scientists as: Clapp (2014), Gertler (1992), Kytzia, Faist and Baccini (2004), Schut, Klerkx and Rodenburg (2015). They investigated 
DOI: 10.14807/ijmp.v11i8.1221

various aspects of the problem of financial balance and regulation of resources in the agricultural sector.

Scientists have established that the resources of activity are represented in the financial balance, by their types, composition and functional role in the process of reproduction of gross output on the one hand and they are represented by the sources of their formation on the other hand. In turn, the structure of the financial balance is the most informative form that allows you to make management decisions at the state level, as it allows you to get objective information about the industry; determine the degree of security of their own funds; to establish, due to what articles the greatest changes took place; to assess the financial condition of the agricultural sector.

In developed countries, as noted by Gertler (1992), the economic conditions governing financial opportunities are investigated, and the structure of the financial balance depends on endogenous factors, even a small change of which has a significant effect on volumes. International institutions and governments develop structural, financial, and management strategies that aim to expand the state's authority in regulating the volume of agricultural financial resources.

Therefore, the current needs of the sustainable development of Ukraine require a more capacious assessment of financial resources, the peculiarities of the formation of their balance, as well as taking into account the conditions for definition and implementation.

\section{GENERAL METHODOLOGICAL APPROACHES.}

In accordance with the order of the Ministry of Economy No. 49/76/117 of April 18, 1996 (LUPENKO; MESEL-VESELIAK, 2012), the balance of financial resources is drawn up in the prescribed form and includes the corresponding main sections, which we supplemented with lower levels of balance for the industry and industry enterprises (Table 1).

Table 1: The method of forming a balance of financial resources

\begin{tabular}{|c|c|}
\hline By income: & By expenditure: \\
\hline \multicolumn{2}{|c|}{ NATIONWIDE } \\
\hline $\begin{array}{l}\text { 1. Budget revenues; } \\
\text { 2. Long-term loans for economic } \\
\text { development; } \\
\text { 3. Resources of enterprises and organizations; } \\
\text { 4. Resources of extra-budgetary funds; } \\
\text { 5. Funds of foreign investors; } \\
\text { 6. Other sources (loans of the National Bank, } \\
\text { issuance of securities, financial assistance of } \\
\text { international financial organizations, etc.) }\end{array}$ & $\begin{array}{l}\text { 1. Budget expenditures; } \\
\text { 2. The costs of implementing national } \\
\text { programs for the development of the national } \\
\text { economy at the expense of long-term loans; } \\
\text { 3. The costs of enterprises and organizations } \\
\text { at the expense of their own resources; } \\
\text { 4. Expenditures of extra-budgetary funds } \\
\text { (without budget funds). }\end{array}$ \\
\hline \multicolumn{2}{|c|}{ INDUSTRY } \\
\hline
\end{tabular}


INDEPENDENT JOURNAL OF MANAGEMENT \& PRODUCTION (IJM\&P)

http://www.ijmp.jor.br

v. 11, n. 8, Special Edition ISE, S\&P - May 2020

ISSN: 2236-269X

DOI: 10.14807/ijmp.v11i8.1221

\begin{tabular}{|c|c|}
\hline By income: & By expenditure: \\
\hline $\begin{array}{l}\text { 1. Budget resources for the agricultural sector } \\
\text { and local budgets for rural development; } \\
\text { 2. Long-term credit resources for the industry; } \\
\text { 3. Resources of agricultural enterprises; } \\
\text { 4. Funds of foreign investors for the } \\
\text { development of agriculture and rural areas; } \\
\text { 5. Other sources }\end{array}$ & $\begin{array}{l}\text { 1. Budget expenditures for industry and rural } \\
\text { development; } \\
\text { 2. Expenses for the implementation of } \\
\text { industry development programs through long-term } \\
\text { loans; } \\
\text { 3. Expenses of industry enterprises at the } \\
\text { expense of their own resources; } \\
\text { 4. Other expenditures }\end{array}$ \\
\hline \multicolumn{2}{|c|}{ INDUSTRY ENTERPRISES } \\
\hline $\begin{array}{l}\text { 1. Profit (after paying the tax); } \\
\text { 2. Depreciation; } \\
\text { 3. State support of individual enterprises; } \\
\text { 4. Other funds }\end{array}$ & $\begin{array}{l}\text { Expenses of enterprises are due to: } \\
\text { own funds } \\
\text { long-term loans } \\
\text { other sources }\end{array}$ \\
\hline
\end{tabular}

Source: Lupenko and Mesel-Veseliak (2012)

Based on the list of incomes and expenses of the balance of financial resources, their low level is formed by the enterprises of the industry. The bulk of the industry's resources is formed depending on their quantity and financial condition.

Thus, the number of business entities in the agrarian is given in Table. 2. As for small businesses, their share in the total number of the Ukrainian economy is $17 \%$ for small and $12 \%$ for micro enterprises. The agricultural sector is below the level of trade and services sectors in the overall structure of small business.

Table 2: Number of Ukrainian enterprises by types of economic activity in 2017

\begin{tabular}{|l|l|l|l|l|l|l|l|l|l|}
\hline \multirow{2}{*}{ Sectors } & \multirow{2}{*}{$\begin{array}{l}\text { Total, } \\
\text { units }\end{array}$} & \multicolumn{2}{|c|}{ Large } & \multicolumn{2}{c|}{ Medium } & \multicolumn{2}{c|}{ Small } & \multicolumn{2}{c|}{ Micro } \\
\cline { 3 - 10 } & units & $\mathbf{\%}$ & units & $\mathbf{\%}$ & units & \% & units & \% \\
\hline Total & 338256 & 399 & 0.1 & 14937 & 4.4 & 322920 & 95.5 & 278102 & 82.2 \\
\hline Agriculture & 50115 & 18 & 0.0 & 2383 & 4.8 & 47714 & 95.2 & 42512 & 84.8 \\
\hline Industry & 42026 & 215 & 0.5 & 4745 & 11.3 & 37066 & 88.2 & 27970 & 66.6 \\
\hline Building & 27468 & 4 & 0.0 & 791 & 2.9 & 26673 & 97.1 & 22458 & 81.8 \\
\hline Trade; Repairs & 89538 & 129 & 0.1 & 2837 & 3.2 & 86572 & 96.7 & 76235 & 85.1 \\
\hline Transport & 15252 & 19 & 0.1 & 1093 & 7.2 & 14140 & 92.7 & 11464 & 75.2 \\
\hline
\end{tabular}

Source: author's calculations based on: The State Statistics Service of Ukraine. Retrieved from: http://ukrstat.gov.ua

The niche occupied by the subjects of small agrarian business (small and micro enterprises) is quite capacious - 95.2\% of the total amount. According to the conducted studies of the dynamics and structure of the added value of agricultural enterprises (Table 3), it was found that in 2012 their share was 28.1\%, and in 2017 it was already 48.5\%, and created added value increased 4.5 times. 
INDEPENDENT JOURNAL OF MANAGEMENT \& PRODUCTION (IJM\&P)

http://www.ijmp.jor.br

v. 11, n. 8, Special Edition ISE, S\&P - May 2020

ISSN: 2236-269X

DOI: 10.14807/ijmp.v11i8.1221

Table 3: Dynamics and structure of value added agricultural enterprises of Ukraine, million UAH

\begin{tabular}{|c|c|c|c|c|c|c|c|c|c|}
\hline \multirow[t]{2}{*}{ Years } & \multirow[t]{2}{*}{ Total } & \multicolumn{2}{|c|}{ Large } & \multicolumn{2}{|c|}{ Medium } & \multicolumn{2}{|c|}{ Small } & \multicolumn{2}{|c|}{ Micro } \\
\hline & & volumes & $\%$ & volumes & $\%$ & volumes & $\%$ & volumes & $\%$ \\
\hline 2012 & 74407.2 & 10491.4 & 14.1 & 43007.4 & 57.8 & 20908.4 & 28.1 & 4910.9 & 6.6 \\
\hline 2013 & 69669.9 & 9893.1 & 14.2 & 34207.9 & 49.1 & 25568.9 & 36.7 & 7803.0 & 11.2 \\
\hline 2014 & 125464.1 & 15683.0 & 12.5 & 59846.4 & 47.7 & 49934.7 & 39.8 & 20325.2 & 16.2 \\
\hline 2015 & 183874.4 & 32361.9 & 17.6 & 94143.7 & 51.2 & 57368.8 & 31.2 & 15445.4 & 8.4 \\
\hline 2016 & 186933.1 & 19814.9 & 10.6 & 96644.4 & 51.7 & 70473.8 & 37.7 & 21871.2 & 11.7 \\
\hline 2017 & 195447.8 & 8780.8 & 4.5 & 91920.6 & 47.1 & 94746.4 & 48.5 & 37310.3 & 19.1 \\
\hline
\end{tabular}

http://ukrstat.gov.ua

The upward trend in the share of added value depends on government policy of supporting it, primarily in the agrarian sector, which and is manifested in direct and indirect state support, credit programs, international assistance, etc.

The structure of the financial balance of agricultural enterprises is shown in Table 4. Added value during the analyzed period was formed with the help of those resources.

Table 4: Balance structure of agricultural enterprises of Ukraine, \%

\begin{tabular}{|c|c|c|c|c|c|c|c|c|c|c|}
\hline \multirow{2}{*}{ Years } & \multicolumn{4}{|c|}{ Assets } & \multicolumn{4}{c|}{ Liabilities } \\
\cline { 2 - 11 } & \multicolumn{2}{|c|}{ Non-current } & \multicolumn{2}{|c|}{ current } & \multicolumn{2}{c|}{ capital } & \multicolumn{2}{c|}{$\begin{array}{c}\text { Long-term } \\
\text { liabilities }\end{array}$} & \multicolumn{2}{c|}{$\begin{array}{c}\text { Current } \\
\text { liabilities }\end{array}$} \\
\cline { 2 - 12 } & Total & Small & Total & Small & Total & Small & Total & Small & Total & Small \\
\hline $\mathbf{2 0 1 2}$ & 36.8 & 45.3 & 63.2 & 54.7 & 53.6 & 56.8 & 12.7 & 15.0 & 33.7 & 28.1 \\
\hline $\mathbf{2 0 1 3}$ & 37.7 & 39.6 & 62.3 & 60.4 & 50.1 & 52.0 & 13.7 & 11.8 & 36.2 & 35.4 \\
\hline $\mathbf{2 0 1 4}$ & 31.5 & 31.3 & 68.5 & 68.7 & 42.0 & 42.5 & 16.1 & 13.1 & 41.9 & 44.8 \\
\hline $\mathbf{2 0 1 5}$ & 25.0 & 21.1 & 75.0 & 78.9 & 40.2 & 36.0 & 9.9 & 8.1 & 49.9 & 55.9 \\
\hline $\mathbf{2 0 1 6}$ & 14.2 & 8.0 & 85.8 & 92.0 & 24.1 & 13.9 & 4.0 & 1.9 & 71.9 & 84.2 \\
\hline $\mathbf{2 0 1 7}$ & 29.9 & 30.2 & 70.1 & 69.4 & 47.9 & 46.7 & 6.5 & 5.1 & 45.7 & 47.9 \\
\hline
\end{tabular}

Source: author's calculations based on: The State Statistics Service of Ukraine (http://ukrstat.gov.ua)

If in 2012 the non-current assets of small enterprises accounted for $45.3 \%$ of the balance, then they were $30.2 \%$ in 2017 . For the same enterprises, the share of current assets in 2017 was $69.4 \%$. The share of own capital decreased from $56.8 \%$ to $46.7 \%$, long-term liabilities reduced sharply, from $15 \%$ to $5.1 \%$, and current rose from $28.1 \%$ to $47.8 \%$. Primarily, financial resources are generated from outside sources, but the share of short-term loans does not exceed $16 \%$ of current liabilities for this period.

Some scholars take into account significant factors and conditions to assess the financial balance: take into account the indicators and criteria that determine the effectiveness of financial flows; foresee the orientation of indicators on solving problems of calculating the balance; adhere to consistency in the collection, synthesis and analysis of the information base; provide for marketing research to obtain reasonable results in the analysis process (HUDZ, 2015). The main financial indicators are given in Table 5. 
DOI: 10.14807/ijmp.v11i8.1221

Table 5: The financial state of the Ukrainian agricultural enterprises for 2012-2017

\begin{tabular}{|c|c|c|c|c|c|c|}
\hline Main financial indicators & $\mathbf{2 0 1 2}$ & $\mathbf{2 0 1 3}$ & $\mathbf{2 0 1 4}$ & $\mathbf{2 0 1 5}$ & $\mathbf{2 0 1 6}$ & $\mathbf{2 0 1 7}$ \\
\hline Net profit, UAH million & 26787.2 & 14984.5 & 21481.3 & 102849.1 & 90613.2 & 68858.5 \\
\hline Profitability of activity,\% & 21.7 & 11.3 & 20.6 & 41.7 & 32.4 & 22.4 \\
\hline
\end{tabular}

Source: author's calculations based on: The State Statistics Service of Ukraine (http://ukrstat.gov.ua)

According to our previous research (PORTNA, 2017; RADCHENKO, 2018; SCHUT, 2015) in terms of the composition and structure of the financial potential of the agrarian sector, it has been established that its dynamics have tended to increase in the last three years, but have lost ground in 2017. The growth was due to the factors determining the general state of the economy. The size of each individual type of balance structure depends on a combination of factors, among which are the magnitude and trends in macroeconomic development indicators (GDP, inflation rate), the state budget, the balance of payments, the legislative and regulatory framework, the level of solvency of market counterparties, the effectiveness of social and economic policy, the impact of the global financial system, etc. For the agricultural sector these are growth indices of agricultural production, prices for sales of products of the industry, state of profit before tax, etc.

From the sources available for analysis (Figure 1), it was determined that the structure of financial resources of the agricultural sector, which the market offers, the largest share is taken up by the company's own resources - 90\% in 2017 and 70\% in 2012, and state, market and investment resources are insignificant even in aggregate. The reason for this is the fact that it is the own resources that are taken into account in the financial reporting system, and for other factors - the State Statistics Committee is formed mainly by the calculation method.

The growth of balance sheet indicators since 2015 occurs mainly due to price and inflationary factors, an increase in profit with constant production volumes. The current trend of increasing the share of borrowed resources in liabilities and current assets in the asset balance from 2012 to 2017.

The resources offered by the financial and credit infrastructure for the agricultural sector of Ukraine in 2012 amounted to $27 \%$ of their own capital, decreasing over years to $15 \%$ in 2017 year. 
DOI: 10.14807/ijmp.v11i8.1221

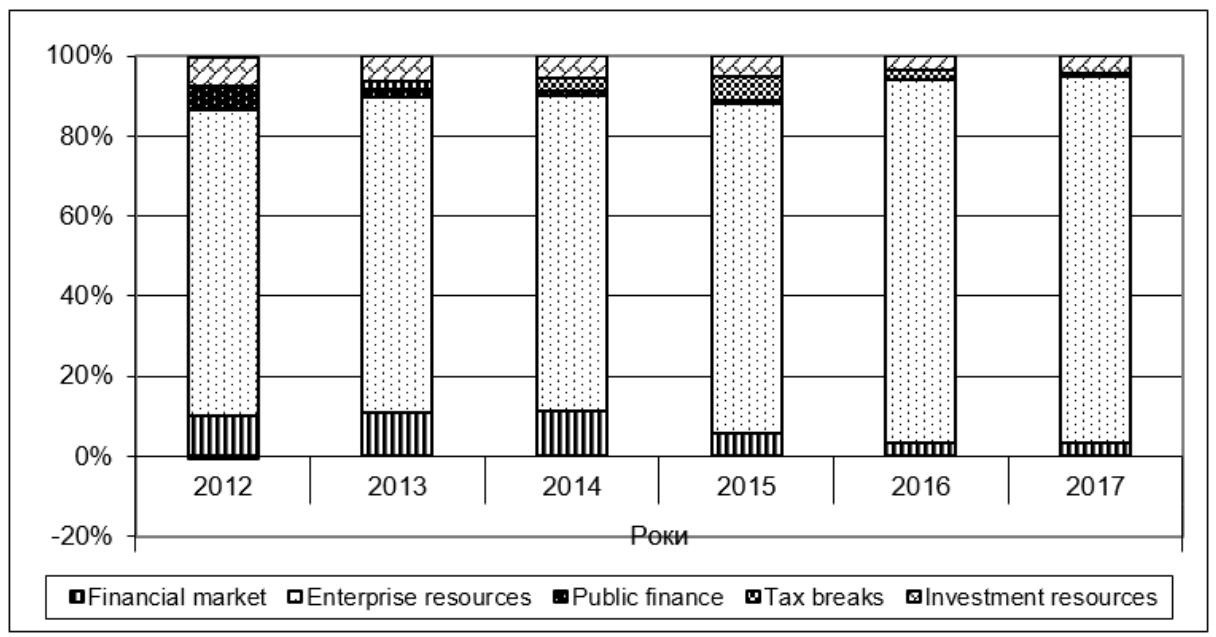

Figure 1: Dynamics of the structure of financial resources of the agricultural sector for 20122017, \%

Source: author's calculations based on: (The State Fiscal Service of Ukraine), Retrieved from: http://sfs.gov.ua/; The State Treasury of Ukraine. Retrieved from: http://www.treasury.gov.ua/main/uk/index; The State Statistics Service of Ukraine. Retrieved from: http://ukrstat.gov.ua.

The dynamics of individual indicators of the formation of the financial potential of the agricultural sector for 2012-2017 is given in Table 6 .

Table 6: Dynamics of indicators of the financial potential of the agricultural sector for 20122017, billion UAH

\begin{tabular}{|l|c|c|c|c|c|c|}
\hline \multicolumn{1}{|c|}{ Indicators } & $\mathbf{2 0 1 2}$ & $\mathbf{2 0 1 3}$ & $\mathbf{2 0 1 4}$ & $\mathbf{2 0 1 5}$ & $\mathbf{2 0 1 6}$ & $\mathbf{2 0 1 7}$ \\
\hline Attracted Bank Loans & 36.5 & 43.5 & 55.3 & 48.4 & 55.4 & 60.5 \\
\hline Budget Financing & 4.30 & 3.61 & 2.64 & 0.52 & 0.60 & 5.80 \\
\hline Insurance Premiums & 0.13 & 0.14 & 0.07 & 0.08 & 0.16 & 0.20 \\
\hline Enterprise Resources & 276.7 & 313.1 & 390.6 & 685.8 & 1537.3 & 911.6 \\
\hline
\end{tabular}

Source: author's calculations based on: The State Fiscal Service of Ukraine. Retrieved from: http://sfs.gov.ua/; The State Treasury of Ukraine. Retrieved from: http://www.treasury.gov.ua/main/uk/index; The State Statistics Service of Ukraine. Retrieved from: http://ukrstat.gov.ua

If in 2017 the amount of financial potential of the agricultural sector amounted to about 1024 billion UAH (37 billion US dollars), then for the period up to 2020 it is expected to grow to 1915 billion UAH (68 billion US dollars), or 83\%. That is, it is assumed that it can grow annually by no less than 215 billion UAH (15-20\%) in the next 3-5 years and by the end of 2020. Against the 2015 level, it will increase 2.5 times. The potential of rural development in 2017 reached almost 45 billion US dollars and up to 2020 and it is expected to grow by 76\% or to 80 billion US dollars (PORTNA, 2017).

Kytzia et al have developed an advanced analysis method (EE-MFA). The aim of this analysis is to study the causal relationships of the production chain to create a model of material, energy and cash flows as the basis for a multi-criteria evaluation of strategies to 
DOI: 10.14807/ijmp.v11i8.1221

improve resource use efficiency, classifying strategies by impact potential (KYTZIA; FAIST; BACCINI, 2004).

Schut et al. (2015) offer an assessment of agricultural innovation systems for RAAIS - a diagnostic tool that analyzes complex agricultural problems and innovative capacity of the industry through: an integrated analysis of technological, social and cultural, economic, institutional, and political aspects; interaction of different levels (national, regional, local) takes into account the interests of the parties (farmers, government). In the end, the need to strengthen the state regulation in this area in the works of Clapp (2014) is justified by the fact that private capital does not invest in agriculture without state guarantees and support and this creates the need for government regulation of private finances.

The given data concern only the enterprises of the agrarian business that make up the financial statements. But commodity farms remain without attention. One of the most difficult is the problem of financial support for the rural population and in the first place, lending to the development of personal subsidiary farms. Lack of financial resources has a negative effect on all categories of agrarian business, but it is the latter that suffer most from the lack of funding, since banks do not work with this segment as full-fledged borrowers.

Thus, the methodological basis for the formation of the financial balance of the agrarian sector is enriched by new phenomena of domestic and foreign practice. Improving the methodology of its formation and functioning is the basis for achieving sustainable long-term development of the agricultural sector and providing it with sufficient financial resources. In this way, it is necessary to take into account both domestic and international experience.

\section{CONCLUSIONS}

So, the system of forming a financial balance goes beyond the mechanical consolidation of financial statements of agricultural enterprises and also includes the resources of such entities as the state, the financial market (banks, business support funds (including international), insurance and leasing companies) etc. Currently, it has been significantly expanded with new terms and categories and goes beyond the Methodological Recommendations for the Formation of Financial Balance (1996). In addition, industry specifics are vaguely described in this document. In this study, we opened them up more deeply.

Analysis of the state of agrarian enterprises shows that they mainly work at the expense of their own resources, the share of which is still not sufficient for expanded reproduction. 
DOI: 10.14807/ijmp.v11i8.1221

Limited own financial resources necessitates increased access to external resources, the development of both bank and partner lending forms.

It has been established that the existing structure of the financial balance of the industry is not optimal, but unbalanced. The insufficient level of financial resources of the industry to ensure sustainable development has been established, since the balance is not coordinated in vertical and horizontal structures. It provides the solution of the tasks of strategic development, provided for the concept and strategy of development of agriculture and rural areas only by 60$65 \%$ to the real need of financial resources. At the same time, the used sources of financial resources do not directly affect profitability indicators, since ensuring the profitable production of agricultural products depends on the price situation and restraining the growth of production costs, including inflationary ones. This factor must be considered when expanding the method of forming a balance.

It is necessary to expand the sources of financial resources in the conditions of state regulation, namely, to stimulate the participation of banks, non-bank financial institutions and institutional investors in expanding their participation in the development of the financial balance system; the development and improvement of the regulatory and legal framework for the protection of the economic interests of farms by providing specific credit products; target support. A very promising area maybe an increase in lending through government guarantees.

Weighty problem is formed at the intersection of this study. It is the most important conclusion of our research: How do the financial balance, financial resources and financial potential of the agricultural sector compare with each other? Approaches to solving this problem are the important areas for our further researches.

\section{REFERENCES}

CLAPP, J. (2014) Financialization, distance and global food politics. Journal of Peasant Studies, v. 41, is. 5, p. 797-814.

GERTLER, M. (1992) Financial capacity and output fluctuations in an economy with multiperiod financial relationships. The Review of Economic Studies, v. 59, is. 3, p. 455-472. DOI: 10.2307/2297859. https://www.jstor.org/stable/2297859.

KORNIJCHUK, G. V. (2015) Theoretical bases of development of financial potential of agro-formations. Pershyi nezalezhnyi naukovyi visnyk, n. 5, p. 60-62. (in Ukranian)

KYTZIA, S.; FAIST, M.; BACCINI, P. (2004) Economically extended - MFA: a material flow approach for a better understanding of food production chain. Journal of Cleaner Production, v. 12, n. 8-10, p. 877-889.

LUPENKO, YU. O.; MESEL-VESELIAK, V. I. (2012) Strategic directions of development of agriculture of Ukraine for the periodtill 2020. Kyiv: NNCz«Insty tut 
DOI: 10.14807/ijmp.v11i8.1221

agrarnoyi ekonomiky`». (in Ukranian)

LEGISLATION OF UKRAINE (201?) On approval of methodological instructions for compiling the balance of financial resources approved by the order of the ministry of economy №49/76/117 18.04.96. Retrieved from https://zakon.rada.gov.ua/laws/show/z022096/ed19960507/find?text=\%C1\%E0\%EB\%E0\%ED\%F1+\%F4\%B3\%ED\%E0\%ED\%F1\%EE \%E2\%E8\%F5+\%F0\%E5\%F1\%F3\%F0\%F1\%B3\%E2 (in Ukranian)

PORTNA, O. V. (2017) Architectonics of the aggregate financial potential of Ukraine: positive synergetic effects and aggregate risks. Problemy ekonomiky, v. 1, p. 122-127. (in Ukranian)

RADCHENKO, O. D. (2019) Financial potential of sustainable development of the agrarian sector. Economics of AIC, v. 1, p. 27-38. (in Ukranian)

RADCHENKO, O. D.; LAZUTINA, L. O. (2018) Methodological approaches to assessing the financial potential of Ukraine's rural development. Agrarnaya ekonomika, v. 12, p. 5258. (in Ukranian)

RADCHENKO, O. D. (2018) Support to the agricultural sector over the millennium credit mechanism. Collection of scientific works of the State Fiscal University Service of Ukraine: electronic scientific publication, v. 1, p. 161-177. (in Ukranian)

SCHUT, M.; KLERKX, L.; RODENBURG, J.; KAYEKE, J.; HINNOU, L. C.; RABOANARIELINA, C. M.; BASTIAANS, L. (2015) RAAIS: Rapid Appraisal of Agricultural Innovation Systems (Part I). A diagnostic tool for integrated analysis of complex problems and innovation capacity. Agricultural Systems, v. 132, p. 1-11.

SEMENYSHENA, N. V.; RADCHENKO, O. D. (2010) Information provision for estimating the potential of agrarian enterprises. Bulletin of the Sumy National Agrarian University. Series: Finance and Credit, v. 1, p.236-239. (in Ukranian)

SHABATURA, T. S.; LAHODIIENKO, N. V. (2015) Methodological support of realization of financial potential of the enterprise of agrarian production. Ekonomichnyi analiz, v. 3, n. 19, p. 101-106. (in Ukranian)

TRUSOVA, N. V. (2017) Financial potential of agrarian enterprises. Melitopol: TOV «Vydavnychyi budynok MMD». (in Ukranian)

YE, H. O. (2015) Diagnostics and management of financial potential of the enterprise. Oblik i finansy, v. 1, n. 67, p. 71-76. 